\title{
Endothelial Nitric Oxide Synthase Is Expressed in Cultured Human Bronchiolar Epithelium
}

\author{
Philip W. Shaul, * Amy J. North, “ Leeju C. Wu, ${ }^{\star}$ Lieselotte B. Wells, ${ }^{*}$ Timothy S. Brannon, ${ }^{\star}$ Kim S. Lau, ${ }^{\S}$ Thomas Michel, \\ Linda R. Margraf," and Robert A. Star* \\ Departments of *Pediatrics, ${ }^{\ddagger}$ Internal Medicine, ${ }^{\S}$ Physiology, and "Pathology, University of Texas Southwestern Medical Center, Dallas, \\ Texas 75235; and 'Cardiovascular Division, Brigham and Women's Hospital, Harvard Medical School, Boston, Massachusetts 02115
}

\section{Abstract}

Nitric oxide (NO) is an important mediator of physiologic and inflammatory processes in the lung. To better understand the role of NO in the airway, we examined constitutive NO synthase (NOS) gene expression and function in NCIH441 human bronchiolar epithelial cells, which are believed to be of Clara cell lineage. NOS activity was detected by $\left[{ }^{3} \mathrm{H}\right]$ arginine to $\left[{ }^{3} \mathrm{H}\right]$ citrulline conversion $(1,070 \pm 260 \mathrm{fmol} /$ mg protein per minute); enzyme activity was inhibited $91 \%$ by EGTA, consistent with the expression of a calcium-dependent NOS isoform. Immunoblot analyses with antisera directed against neuronal, inducible, or endothelial NOS revealed expression solely of endothelial NOS protein. Immunocytochemistry for endothelial NOS revealed staining predominantly in the cell periphery, consistent with the association of this isoform with the cellular membrane. To definitively identify the NOS isoform expressed in H441 cells, NOS cDNA was obtained by degenerate PCR. Sequencing of the H441 NOS cDNA revealed $100 \%$ identity with human endothelial NOS at the amino acid level. Furthermore, the H441 NOS cDNA hybridized to a single 4.7kb mRNA species in poly (A) ${ }^{+}$RNA isolated from $\mathrm{H} 441$ cells, from rat, sheep, and pig lung, and from ovine endothelial cells, coinciding with the predicted size of $4.7 \mathrm{~kb}$ for endothelial NOS mRNA. Guanylyl cyclase activity in $\mathbf{H 4 4 1}$ cells, assessed by measuring cGMP accumulation, rose 6.6and 5.4-fold with calcium-mediated activation of NOS by thapsigargin and A23187, respectively. These findings indicate that endothelial NOS is expressed in select bronchiolar epithelial cells, where it may have autocrine effects through activation of guanylyl cyclase. Based on these observations and the previous identification of endothelial NOS in a kidney epithelial cell line, it is postulated that endothelial NOS may be expressed in unique subsets of epithelial cells in a variety of organs, serving to modulate ion flux and/or secretory function. (J. Clin. Invest. 1994. 94:2231-2236.) Key words: airway • Clara cells • guanylyl cyclase $\bullet$ messenger RNA $\cdot$ polymerase chain reaction

Address correspondence to Dr. Philip W. Shaul, Department of Pediatrics, University of Texas Southwestern Medical Center, 5323 Harry Hines Blvd., Dallas, TX 75235. 1994.

Received for publication 10 June 1994 and in revised form 5 August

J. Clin. Invest.

(c) The American Society for Clinical Investigation, Inc.

$0021-9738 / 94 / 12 / 2231 / 06 \$ 2.00$

Volume 94, December 1994, 2231-2236

\section{Introduction}

Nitric oxide (NO $)^{1}$ is an important mediator of numerous physiologic and inflammatory processes in the lung. It is produced from L-arginine upon conversion to L-citrulline by the enzyme NO synthase (NOS) in a reaction which requires molecular oxygen. NOS is a family of enzymes which currently consists of three major isoforms. The neuronal and endothelial isoforms are believed to be constitutive in nature, while the third isoform originally studied in the macrophage is induced by a variety of cytokines (1).

A role for NO in physiologic processes in the airway is suggested from both in vivo and in vitro studies. Inhaled gaseous NO and aerosolized NO-releasing compounds produce potent bronchodilation in guinea pigs (2), and endothelium-derived NO relaxes tracheal smooth muscle in vitro (3). In addition, endogenous NO gas is present in the exhaled air of animals and humans (4), and endogenous nitrogen oxides and bronchodilator $S$-nitrosothiols have been demonstrated in human airways (5). Furthermore, air or helium embolization of the rabbit pulmonary artery does not alter exhaled NO concentrations, suggesting that the exhaled NO may be derived from the bronchial tree and not the pulmonary vasculature (4).

There is indirect evidence that the epithelium may be a source of NO production in the airway. In the canine bronchial tree, the epithelium releases a relaxing factor which reduces contractile responses in larger airways and enhances relaxation responses in smaller airways (6). Immunohistochemical studies in the rat using NADPH diaphorase staining indicative of NOS activity and antisera which recognize neuronal and endothelial NOS localize NOS to the airway epithelium $(7,8)$. In human lung, it has been reported that NADPH diaphorase staining is evident throughout the airway epithelium but staining for constitutive NOS isoforms is negative, whereas large airway epithelium stains positive for inducible NOS (7). There are preliminary reports of NOS expression and activity in cultured human airway epithelium $(9,10)$, but the isoform(s) constitutively expressed in those cells has not been fully characterized.

The purpose of this investigation was to examine constitutive NOS gene expression and function in NCI-H441 human bronchiolar epithelial cells, which originated from a papillary adenocarcinoma $(11,12)$. Experiments were performed to address the following questions: $(a)$ Is NOS activity present in human bronchiolar epithelial cells?; $(b)$ Which NOS isoform( $s$ ) is expressed?; and (c) Does NO have autocrine effects in bronchiolar epithelium?

1. Abbreviations used in this paper: FMN, flavin mononucleotide; IBMX, isobutylmethylxanthine; L-NAME, nitro-L-arginine methyl ester; NO, nitric oxide; NOS, nitric oxide synthase; PAEC, pulmonary artery endothelial cells. 


\section{Methods}

H441 cell culture. NCI-H441 cells (passages 4-11, ATTC) were propagated in RPMI medium containing $10 \%$ fetal calf serum, $1 \%$ L-glutamine, $1 \%$ antibiotic/antimycotic mixture, $0.5 \%$ ampicillin, $0.15 \%$ Nystatin, $0.15 \%$ Gentamycin, and $0.10 \%$ Tylosin in a humidified incubator with $5 \% \mathrm{CO}_{2}$ in air at $37^{\circ} \mathrm{C}$. These cells exhibit epithelial morphology, Clara cell granules and lamellar bodies are evident by electron microscopy, and they express the major surfactant apoproteins SP-A, SP-B, and SP-D, indicating that they are most likely of Clara cell lineage (1214). The use of this continuous cell line allows for specific examination of epithelial cell NOS expression and function without contamination by resident macrophages or endothelial cells which are present in primary cell cultures.

NOS activity. Subconfluent $\mathrm{H} 441$ cells washed with ice-cold PBS ( $100 \mathrm{mM} \mathrm{NaCl}, 25 \mathrm{mM} \mathrm{NaH} \mathrm{PO}_{4}, 80 \mathrm{mM} \mathrm{Na}_{2} \mathrm{HPO}_{4}, \mathrm{pH} 7.5$ ) were pelleted and resuspended in ice-cold $50 \mathrm{mM}$ Tris buffer ( $\mathrm{pH} 7.4$ ) containing $1.0 \mathrm{mM}$ EDTA, $5 \mathrm{mM}$ mercaptoethanol, $10 \mu \mathrm{g} / \mathrm{ml}$ pepstatin A, $10 \mu \mathrm{g} / \mathrm{ml}$ leupeptin, $90 \mu \mathrm{g} / \mathrm{ml}$ phenylmethylsulfonyl fluoride, and 1.0 $\mu \mathrm{M}$ tetrahydrobiopterin. The cells were disrupted by freeze-thawing in liquid nitrogen. NOS activity in the preparation was determined by measuring the conversion of $\left[{ }^{3} \mathrm{H}\right]$ arginine to $\left[{ }^{3} \mathrm{H}\right]$ citrulline (15). $50 \mu \mathrm{l}$ of cell preparation was added to $50 \mu \mathrm{l}$ of buffer yielding final concentrations of reagents as follows: $2 \mathrm{mM}$ beta-NADPH, $2 \mu \mathrm{M}$ tetrahydrobiopterin, $10 \mu \mathrm{M}$ flavin adenine dinucleotide, $10 \mu \mathrm{M}$ flavin mononucleotide (FMN), $0.5 \mathrm{mM} \mathrm{CaCl}_{2}$ in excess of EDTA, $15 \mathrm{nM}$ calmodulin, $2 \mu \mathrm{M}$ cold L-arginine, and $2.0 \mu \mathrm{Ci} / \mathrm{ml}\left[{ }^{3} \mathrm{H}\right] \mathrm{L}$-arginine. After incubation at $37^{\circ} \mathrm{C}$ for $30 \mathrm{~min}$, the assay was terminated by the addition of $400 \mu \mathrm{l}$ of $40 \mathrm{mM}$ Hepes buffer, pH 5.5, with $2 \mathrm{mM}$ EDTA and 2 mM EGTA. The terminated reactions were applied to $1-\mathrm{ml}$ columns of Dowex AG50WX-8 (Tris form) and eluted with $1 \mathrm{ml}$ of the $40 \mathrm{mM}$ Hepes buffer. $\left[{ }^{3} \mathrm{H}\right]$ Citrulline was collected in scintillation vials and quantified by liquid scintillation spectroscopy. NOS activity was evaluated in the presence and absence of $2.0 \mathrm{mM}$ nitro-L-arginine methyl ester ( $\mathrm{L}$ NAME). NOS activity was also assayed in ovine fetal pulmonary artery endothelial cells (PAEC) to serve as a positive control (16). In preliminary experiments, NOS activity was linear with time for up to $1 \mathrm{~h}$.

Immunoblot analysis and immunocytochemistry. The methods used for immunoblot analysis generally followed those we have reported previously (17). Subconfluent $\mathrm{H} 441$ cells were harvested in ice-cold PBS, pelleted, resuspended in $50 \mathrm{mM} \mathrm{KH}_{2} \mathrm{PO}_{4}$ buffer ( $\mathrm{pH} 7.8$ ) containing $250 \mathrm{mM}$ mannitol, $5 \mathrm{mM}$ disodium EDTA, $0.1 \mathrm{mM}$ diethyldithiocarbamate, $0.1 \mathrm{mM}$ indomethacin, and $1 \%$ Tween 20 , and ultrasonically disrupted (Branson Ultrasonics Corp., Danbury, CT). The protein content of the preparation was determined by the method of Bradford (18) using bovine serum albumin as the standard. SDS-PAGE was performed on 100-200 $\mu \mathrm{g}$ protein with $7 \%$ acrylamide using the method of Laemmli (19), and the proteins were electrophoretically transferred to nitrocellulose filters. The filters were blocked for $1.5 \mathrm{~h}$ in buffer containing $150 \mathrm{mM} \mathrm{NaCl}$ and $10 \mathrm{mM}$ Tris ( $\mathrm{pH} \mathrm{7.5)}$ with $0.5 \%$ Tween 20 and $5 \%$ dried milk, and incubated overnight at $4^{\circ} \mathrm{C}$ with primary antisera generated to peptides unique to either neuronal, inducible, or endothelial NOS. The antisera were directed against the $\mathrm{COOH}$-terminal peptide ESKKDTDEVFSS of human neuronal NOS (20), a mid-molecule peptide of murine inducible NOS (Lowenstein, C. J., G. Allen, N. Rose, S. H. Snyder, and A. Herskowitz, manuscript submitted for publication), or the mid-molecule peptide PYNSSPRPEQHKSYK of endothelial NOS, which corresponds to a conserved epitope identical in sequence between bovine and human $(21,22)$. The antiserum to inducible NOS was the kind gift of Dr. Charles Lowenstein (Department of Medicine, Johns Hopkins University School of Medicine, Baltimore, MD).

After incubation with primary antiserum, the nitrocellulose filters were washed with the $150 \mathrm{mM} \mathrm{NaCl}$ buffer with Tween 20 and incubated for $1.5 \mathrm{~h}$ with a 1:5,000 dilution of a donkey anti-rabbit Ig antibody horseradish peroxidase conjugate (Amersham International, Buckinghamshire, United Kingdom). The filters were washed in the $150 \mathrm{mM} \mathrm{NaCl}$ buffer with Tween 20, and the bands for NOS were visualized by chemiluminescence (ECL Western blotting analysis system; Amersham International). Homogenates from rat cerebellum, from LPS-stimulated murine macrophages, and from ovine PAEC were used as positive controls for neuronal, inducible, and endothelial NOS protein, respectively.

Immunocytochemistry was performed on preparations of the $\mathrm{H} 441$ cells to further localize the NOS within the cells and to confirm that the NOS detected by immunoblot analysis was not derived from contaminating cells. Staining for endothelial NOS protein was performed on $100 \%$ ethanol-fixed cytospin preparations and ethanol-formalin-fixed cell block preparations embedded in paraffin and routinely processed for light microscopy. After treatment with $3 \%$ hydrogen peroxide to block endogenous peroxidases, sections were incubated overnight with a 1:200 dilution of primary endothelial NOS antiserum. Specific binding was detected using biotinylated anti-mouse and anti-rabbit immunoglobulin and peroxidase-conjugated streptavidin (Dako Corp., Carpinteria, CA). Slides were counterstained with hematoxylin. Negative control sections incubated in preimmune rabbit serum or $0.5 \mathrm{M}$ Tris-buffered saline were run concurrently. Cultured ovine PAEC served as a positive control. To confirm the specificity of the staining, in selected sections $100 \mu \mathrm{g} / \mathrm{ml}$ of the purified endothelial NOS peptide was added to the immune serum before incubation to adsorb the endothelial NOS antibody. To confirm that endothelial cell contamination was not present in the H441 cultures, deparaffinized cell block sections were immunostained with antisera directed against the endothelial cell markers Factor VIII-related antigen (BioGenex Labs, San Ramon, CA) and Ulex europaeus agglutinin I lectin (Vector Labs, Inc., Burlingame, CA) using avidin-biotin methodology as described above (23). Sections of ovine PAEC were run concurrently as positive controls for endothelium.

Degenerate PCR for H44I NOS cDNA. Total cellular RNA was obtained and purified from subconfluent $\mathrm{H} 441$ cells by a single extraction method with an acid guanidinium thiocyanate-phenol-chloroform mixture $(17,24)$. cDNA was made from $5 \mu \mathrm{g}$ of total RNA using oligo $(\mathrm{dT})_{15}$ (Promega Corp., Madison, WI) and Moloney murine leukemia virus reverse transcriptase (GIBCO BRL, Gaithersburg, MD) as described previously (25). Regions of high homology in the FMN binding domain and in the NADPH binding domain were selected on the basis of published rat neuronal NOS (26), murine inducible NOS (27), and human endothelial NOS (22) sequences for the design of fully degenerate oligonucleotide primers (25). The FMN and NADPH binding domains are on exons 16 and 23 , respectively, of the human endothelial NOS gene (28). The sense oligonucleotide [GCC GAA TTC GGT ACC ATG TA(C/T) CC (A/C/T/G) CA(A/C/T/G) TT(C/T) TG (C/T) GC: 5' to 3'] coded for amino acids MYPQFCA; the antisense oligonucleotide [GAA TTC TAG AGG ATC CGG (A/C/T/G)GC (A/ $\mathrm{T} / \mathrm{G}) \mathrm{AT}(\mathrm{A} / \mathrm{C} / \mathrm{T} / \mathrm{G}) \mathrm{CC}(\mathrm{A} / \mathrm{C} / \mathrm{T} / \mathrm{G}) \mathrm{GT}(\mathrm{A} / \mathrm{C} / \mathrm{T} / \mathrm{G}) \mathrm{CC}(\mathrm{A} / \mathrm{C} / \mathrm{T} /$ G)GG (A/C/T/G)CC; 5' to $3^{\prime}$ ] coded for amino acids GPGTGIAP. Both oligonucleotides contained a 15-base polylinker at the $5^{\prime}$ end for cloning purposes. Rat endothelial NOS cDNA (17) and RNA from sheep PAEC were used as positive controls. In selected samples of H441 RNA, the reverse transcriptase was omitted to control for amplification from contaminating cDNA or genomic DNA. A single PCR product of the appropriate size was digested with EcoRI and XbaI and was subcloned full-length into pBluescript (Stratagene, La Jolla, CA). The nucleotide sequence of four clones was determined using sequenase (United States Biochemical Corp., Cleveland, $\mathrm{OH}$ ).

Northern analysis. The mRNA species hybridized by H441 NOS cDNA was characterized by Northern analysis of RNA isolated from H441 cells, from pig, sheep, and rat lung, and from ovine fetal PAEC. Total RNA was subjected to oligo-dT affinity chromatography to obtain poly (A) ${ }^{+}$RNA (29). The poly (A) ${ }^{+}$RNA was size-fractionated on $1.0 \%$ agarose formaldehyde gels and transferred to nylon membranes. The quantity of poly (A) ${ }^{+}$RNA used ranged from 5 to $15 \mu \mathrm{g}$. The RNA was cross-linked to the membranes by ultraviolet irradiation. After prehybridization, the membranes were hybridized overnight at $42^{\circ} \mathrm{C}$ in the presence of random-primed ${ }^{32} \mathrm{P}$-labeled $\mathrm{H} 441$ NOS cDNA ( $\left.1.2 \mathrm{~kb}\right)$. After hybridization, the blots were washed, and autoradiography was 


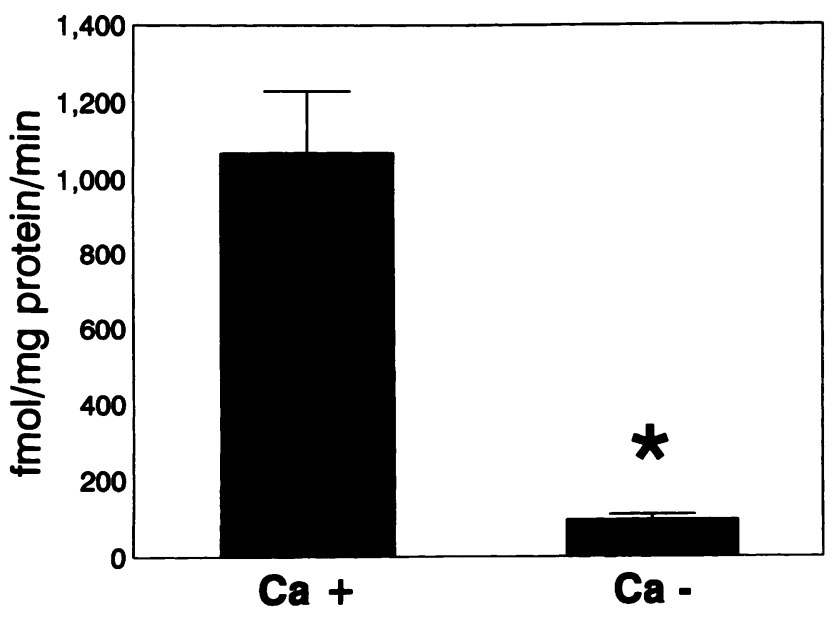

Figure 1. NOS activity in $\mathrm{H} 441$ human bronchiolar epithelial cells. $\left[{ }^{3} \mathrm{H}\right]$ Arginine to $\left[{ }^{3} \mathrm{H}\right]$ citrulline conversion was measured during $30-\mathrm{min}$ incubations in buffer containing $0.5 \mathrm{mM} \mathrm{CaCl}_{2}$, in the absence $(\mathrm{Ca}+)$ or presence of $2.5 \mathrm{mM}$ EGTA ( $\mathrm{Ca}-$ ). Mean \pm SEM, $n=6,{ }^{*} P<0.05$ versus $\mathrm{Ca}+$.

performed. Northern analysis for neuronal NOS and for endothelial NOS (17) was also performed on poly (A) ${ }^{+}$RNA from the $\mathrm{H} 441$ cells.

H441 cell guanylyl cyclase activity. H441 cell guanylyl cyclase activity was assessed by determining the accumulation of cGMP, using methods similar to those used previously in studies of vascular smooth muscle cells (16). Subconfluent cells grown in 24-well plates were washed with Locke's solution, 324 mosM, pH 7.4, containing $154 \mathrm{mM}$ $\mathrm{NaCl}, 5.6 \mathrm{mM} \mathrm{KCl}, 2 \mathrm{mM} \mathrm{CaCl}{ }_{2}, 1 \mathrm{mM} \mathrm{MgCl}, 3.6 \mathrm{mM} \mathrm{NaHCO}{ }_{3}$, $5.6 \mathrm{mM}$ glucose, and $10 \mathrm{mM}$ Hepes. The cells were preincubated at $37^{\circ} \mathrm{C}$ for $10 \mathrm{~min}$ in Locke's solution containing the phosphodiesterase inhibitor isobutylmethylxanthine (IBMX) $(0.5 \mathrm{mM})$. The preincubation solution was replaced with fresh Locke's solution with IBMX to initiate a 5-min incubation performed at $37^{\circ} \mathrm{C}$. Control cells were incubated with IBMX alone. Endogenous NOS activity was stimulated with either thapsigargin $(10 \mu \mathrm{M})$, which releases intracellular calcium stores (30), or with the calcium ionophore A23187 $(10 \mu \mathrm{M})$. The effect of exogenous NO was examined in incubations with IBMX plus sodium nitroprusside $(300 \mu \mathrm{M})(31)$. In selected studies, the effect of NOS inhibition was examined by the addition of $2 \mathrm{mM}$ L-NAME. The incubations were terminated by removing the incubation buffer and placing ice-cold $0.1 \mathrm{M}$ acetic acid, $\mathrm{pH} 3.5$, into the wells. Sodium acetate, $0.1 \mathrm{M}, \mathrm{pH}$ 12 , was added 15 min later, and cGMP content in the supernatant was determined by radioimmunoassay as performed previously (32).

\section{Results}

NOS activity. Constitutive NOS activity of $1,070 \pm 260 \mathrm{fmol} /$ mg protein per minute was detectable in H441 cells (Fig. 1). The level of activity was $\sim 2 \%$ of that measured in positive control endothelial cells $(52.4 \pm 3.9 \mathrm{pmol} / \mathrm{mg}$ protein per minute) studied in the same experiment. NOS activity in the $\mathrm{H} 441$ cells was inhibited $91 \%$ by calcium chelation with $2.5 \mathrm{mM}$ EGTA; 99\% inhibition was evident in the endothelial cells. Comparable findings were obtained in three separate experiments. NOS activity in both cell types was fully inhibited by L-NAME (results not shown).

Immunoblot analyses and immunocytochemistry for NOS. Immunoblot analyses were performed with antisera directed against unique peptide sequences of either neuronal, inducible, or endothelial NOS to further characterize the NOS expressed in the $\mathrm{H} 44 \mathrm{l}$ cells. Immunoblots were positive for endothelial
Figure 2. Immunoblot analysis for endothelial NOS protein in H441 human bronchiolar epithePAEC H441 lial cells. Protein from cultured PAEC was used as a positive control. Signal for endothelial NOS was evident at $135 \mathrm{kD}$. These results are representative of three independent experiments.

NOS protein (Fig. 2). Similar observations were made in three independent experiments. Neuronal and inducible NOS proteins were not detected (results not shown).

Immunohistochemical staining for endothelial NOS protein detected the protein predominantly in the periphery of most H441 cells in the cytospin and cell block preparations (Fig. 3 $A)$. Staining was blocked when the antiserum was preincubated with the endothelial NOS peptide, and it was also absent in slides incubated with preimmune serum or buffer (results not shown). Cultured ovine endothelial cells also exhibited periph-

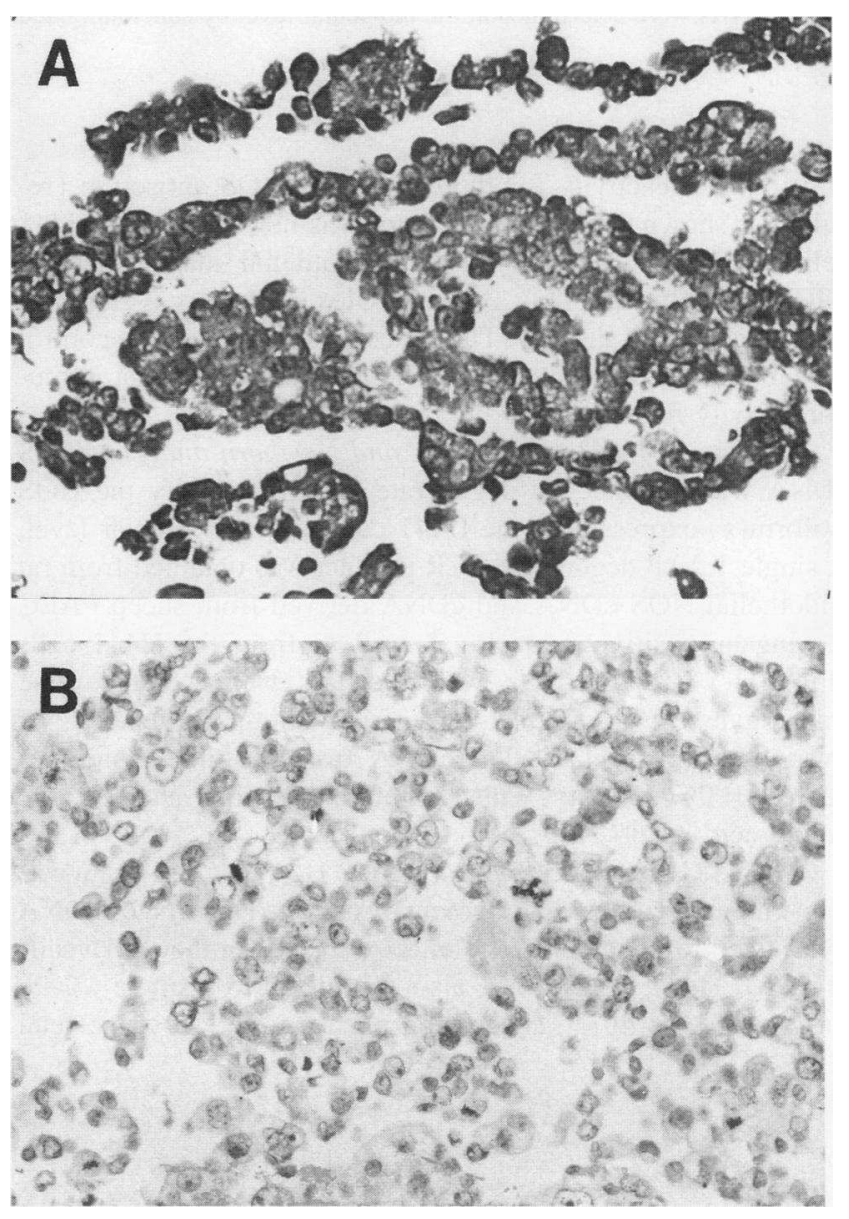

Figure 3. Immunocytochemistry for endothelial NOS protein in H441 human bronchiolar epithelial cells $(A, \times 280)$. Staining for endothelial NOS is evident predominantly in the cell periphery. Staining was blocked when the antiserum was preincubated with the endothelial NOS peptide to which the antiserum was directed, and it was also absent in specimens incubated with preimmune serum or buffer (not shown). Immunoreactivity is not detected in $\mathrm{H} 441$ cell preparations stained for the endothelial marker Factor VIII-related antigen $(B, \times 280)$. 


\section{RAT ENOS}

$\mathrm{Mg}^{2+}$

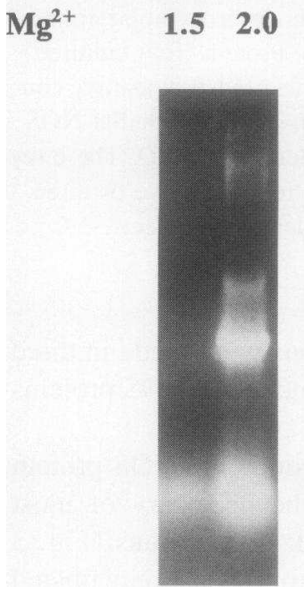

$1.5 \quad 2.0$

1.52 .0
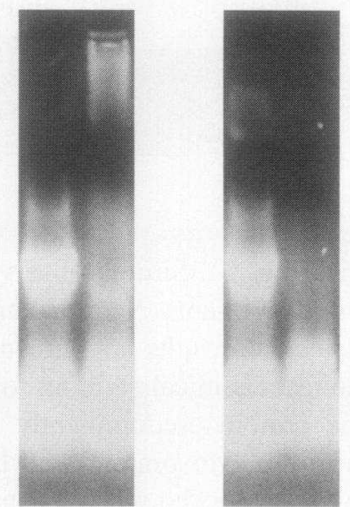

$-1.2 \mathbf{k b}$

Figure 4. Ethidium bromide-stained gel of degenerate PCR products obtained from rat endothelial NOS (ENOS) cDNA and from cDNA derived from sheep PAEC or $\mathrm{H} 441$ cells by reverse transcription. A single 1.2-kb PCR product was obtained from all three specimens, at differing milliMolar concentrations of $\mathrm{Mg}$. The identities of the resultant NOS cDNAs were determined at the molecular level by subcloning and sequencing.

eral immunoreactivity for the endothelial NOS antiserum (results not shown). Immunoreactivity was not detected in H441 cell preparations stained for the endothelial markers Factor VIII-related antigen (Fig. $3 B$ ) and Ulex europaeus agglutinin I lectin (results not shown). The concurrently run positive control preparations of ovine endothelial cells showed abundant immunoreactivity for these markers (results not shown).

Cloning of H44I NOS cDNA and Northern analysis. NOS cDNA was obtained by degenerate PCR to identify the NOS isoform( $\mathrm{s}$ ) expressed in the $\mathrm{H} 441$ cells at the molecular level. A single 1.2-kb degenerate PCR product was obtained from rat endothelial NOS cDNA and cDNA derived from sheep PAEC serving as positive controls, as well as from the H441 cells (Fig. 4). PCR products were not obtained when reverse transcriptase was omitted. After subcloning, sequencing of over $400 \mathrm{bp}$ of H441 NOS cDNA from multiple clones revealed $100 \%$ identity with human endothelial NOS at the amino acid level (22).

The mRNA species hybridized by H441 NOS cDNA was then characterized by Northern analysis. The H441 NOS cDNA hybridized to a single 4.7-kb mRNA species in the H441 cells (Fig. 5). H441 NOS cDNA also hybridized to a single 4.7-kb mRNA species in rat, sheep, and pig lung, and in ovine fetal

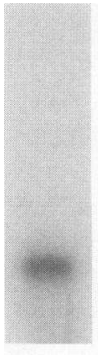

Figure 5. Hybridization of $\mathrm{H} 441$ NOS cDNA obtained by degenerate PCR to poly (A) ${ }^{+}$RNA from $\mathrm{H} 441$ cells. A single $4.7-\mathrm{kb}$ mRNA species is identified. The results are representative of three independent experiments.
LUNG

\section{PAEC}

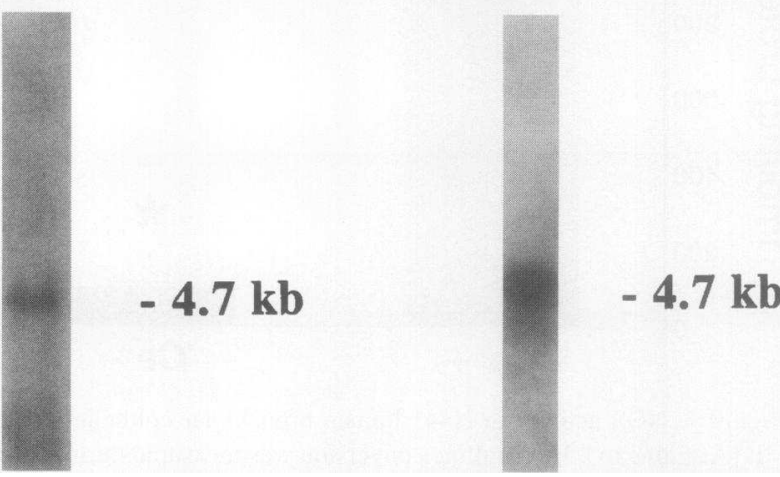

Figure 6. Hybridization of $\mathrm{H} 441 \mathrm{NOS}$ cDNA obtained by degenerate PCR to poly $(\mathrm{A})^{+}$RNA from pig lung and from PAEC. A single $4.7-$ $\mathrm{kb}$ mRNA species is identified. The results are representative of three independent experiments.

pulmonary artery endothelial cells (Fig. 6). Northern analysis for neuronal NOS on poly (A) ${ }^{+}$RNA from the $\mathrm{H} 441$ cells was negative, whereas probing for endothelial NOS was positive (results not shown). All observations made by Northern analysis were replicated in triplicate.

Guanylyl cyclase activity. The potential for autocrine function of endogenous NO was evaluated by measuring $\mathrm{H} 441$ cell guanylyl cyclase activity. Guanylyl cyclase activity was detectable in the $\mathrm{H} 441$ cells and it increased 6.6-fold with thapsigargin and 5.4-fold with A23187 stimulation (Fig. 7). Activity with

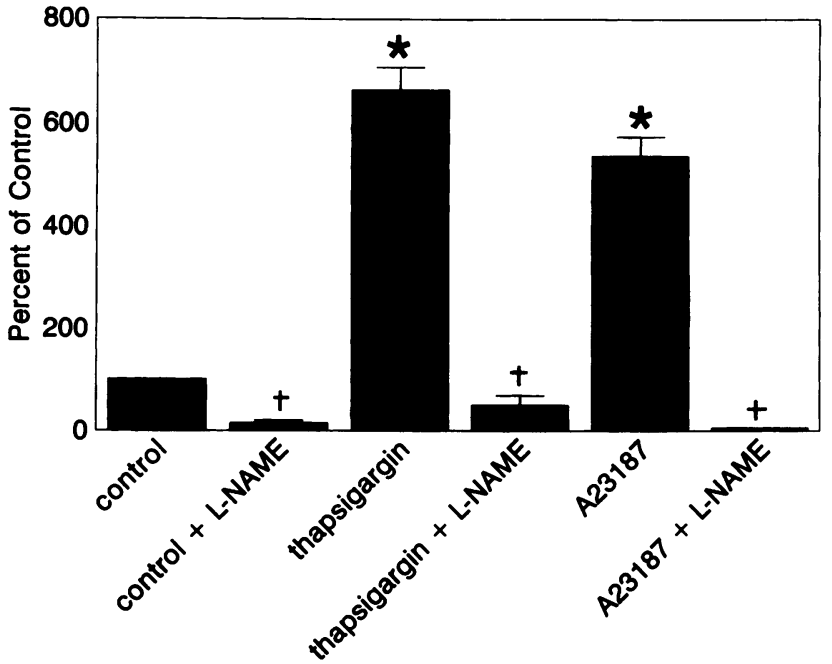

Figure 7. Guanylyl cyclase activity in $\mathrm{H} 441$ human bronchiolar epithelial cells. Cyclic GMP accumulation was measured in cells incubated for 5 min with the phosphodiesterase inhibitor IBMX (control), with thapsigargin ( $10 \mu \mathrm{M})$ plus IBMX, with A23187 (10 $\mu \mathrm{M})$ plus IBMX, or under those conditions in the presence of L-NAME $(2 \mathrm{mM})$. Mean \pm SEM, $n=6 ;{ }^{*} P<0.05$ versus control; ${ }^{\dagger} P<0.05$ versus without L-NAME. Comparable findings were obtained in three separate experiments. 
either thapsigargin or A23187 was fully inhibited by L-NAME. Guanylyl cyclase activity increased $7,127 \pm 317 \%$ with sodium nitroprusside $(n=6, P<0.05)$, and this response was not altered by L-NAME $(6,540 \pm 192 \%, n=6, P<0.05)$. Comparable findings were obtained in three independent experiments.

\section{Discussion}

In this study we examined NOS gene expression and function in NCI-H441 human bronchiolar epithelial cells. We have shown that there is constitutive NOS activity in this cell line due to the expression of the endothelial isoform of the enzyme. To our knowledge, this is the first demonstration of endothelial NOS expression in a nonendothelial pulmonary cell.

We first observed that NOS enzymatic activity in the H441 bronchiolar epithelial cells is calcium dependent, consistent with the expression of either neuronal or endothelial NOS, or a not yet described calcium-calmodulin-dependent isoform. Immunoblot analyses with antisera directed against unique peptide sequences of the three major isoenzymes further revealed that the NOS isoform expressed in the epithelial cells shares epitope (s) with or is identical to endothelial NOS. Immunocytochemistry for endothelial NOS revealed staining predominantly in the periphery of the H441 cells, consistent with the primary association of this isoform with the cellular membrane (21). Northern analysis with the H441 NOS cDNA obtained by degenerate PCR yielded a single $4.7-\mathrm{kb}$ mRNA species not only in the $\mathrm{H} 441$ epithelial cells but also in whole lung from three animal species and in cultured ovine fetal PAEC, coinciding with the predicted size of $4.7 \mathrm{~kb}$ for endothelial NOS mRNA (22). Sequencing of the H441 NOS cDNA then precisely identified the isoform expressed in the human epithelial cells to be endothelial NOS (22).

The expression of NOS in airway epithelium has been explored previously by immunohistochemical methods. In the rat, Schmidt et al. (8) revealed immunostaining of airway epithelium using an antiserum raised against purified neuronal NOS that was reportedly specific to that isoform. Consistent with those findings, Kobzik et al. (7) found NADPH diaphorase staining indicative of NOS activity and immunostaining with antiserum which recognized both neuronal and endothelial NOS. In human lung, Kobzik et al. (7) noted NADPH diaphorase staining throughout the airway epithelium but staining for neuronal and endothelial NOS was negative, whereas large airway epithelium stained positively for inducible NOS. In this study we have used molecular techniques to definitively demonstrate endothelial NOS expression in a human bronchiolar epithelial cell line that is most likely of Clara cell lineage (1114). Our findings contrast with preliminary reports of neuronal NOS expression and activity in primary cultured human bronchial epithelial cells as well as SV40-transformed human bronchial epithelial cells (BEAS-2B) $(9,10)$. Based on these cumulative observations, we conclude that Clara cells express endothelial NOS and that other specific subpopulations of airway epithelium may express neuronal NOS in a constitutive manner. Further studies using in situ hybridization will be required to obtain more definitive information regarding the isoform specificity and the cell specificity of airway epithelial NOS gene expression in vivo.

A physiologic role for NO in the regulation of bronchomotor tone is suggested by the results of both in vitro and in vivo investigations. First, there is evidence that NO is present in the airway in that endogenous NO gas is detectable in the exhaled air of animals and humans (4), and endogenous nitrogen oxides and bronchodilator $S$-nitrisothiols have been detected in human bronchioalveolar lavage fluid and tracheal aspirate (5). It appears that the exhaled NO may be derived from airway cells and not vasculature because its abundance is not altered after embolization of the pulmonary circulation (4). Second, there is in vitro evidence that NO relaxes airway smooth muscle. Stuart-Smith and Vanhoutte (6) demonstrated in the canine bronchial tree that epithelium removal causes a leftward shift of constriction response curves to agents such as acetylcholine. Buga and co-workers (3) demonstrated that endothelium-derived NO and NO from donor compounds relax bovine tracheal smooth muscle. Third, there is in vivo evidence that NO plays a role in the modulation of bronchomotor tone. Inhaled gaseous NO and aerosolized NO-releasing compounds produce bronchodilatation in guinea pigs (2), and the bronchoconstrictor effects of histamine are augmented after nebulized or intravenous administration of L-NAME $(33,34)$. The findings of the present investigation suggest that endothelial NOS expressed constitutively in certain airway epithelial cells is at least one source of endogenous NO which may function in a paracrine fashion to modulate bronchomotor tone. Although we observed that NOS activity is considerably less in pulmonary epithelial versus endothelial cells, the absence of hemoglobin may prolong the half-life of NO in the airway compared with in the vasculature under normal conditions.

In this investigation, we also determined whether NO has autocrine effects in bronchiolar epithelium. We found that guanylyl cyclase activity is detectable in the H441 epithelial cells, and it increases markedly with the activation of endogenous NOS or the provision of exogenous NO. Cyclic GMP is an important modulator of intracellular calcium homeostasis (35), which regulates ion transport across Clara cells (36). As such, endothelial NOS may play an important autocrine role in airway epithelial cell ion flux. It has been reported recently that the tracheal instillation of NO in late gestation fetal lambs decreases lung liquid secretion (37), suggesting that such a mechanism may be active in vivo. In addition, since NO serves as a secretagogue in other cell types (38), it may also be involved in Clara cell secretion of the major surfactant apoproteins SP-A, SP-B, and SP-D, or the $10-\mathrm{kD}$ Clara cell secretory protein which has immunomodulatory and antiinflammatory properties $(12,13$, 39). Furthermore, since Clara cells serve as progenitors for both nonciliated and ciliated airway epithelium (14) and NO modulates the growth of other cell types such as vascular smooth muscle (40), endothelial NOS may also play a role in the regulation of the growth and differentiation of both normal and neoplastic airway epithelium. A degree of caution may be warranted, however, in the direct extrapolation of the present findings in a continuous cell line to processes in airway epithelium in vivo.

The present observation of endothelial NOS gene expression in airway epithelium also adds to our understanding of epithelial cells in general. Tracey et al. (41) recently reported the identification of an endothelial-like NOS in LLC-PK ${ }_{1}$ kidney epithelial cells. There is considerable evidence suggesting that a kidney epithelial NOS may be critically involved in the regulation of renal function (42-44). As in the airway, however, the epithelial cells of the kidney tubule are not a homogeneous population. Based on the present findings and those of Tracey and co-workers (41), we postulate that endothelial NOS may 
be expressed in unique subsets of epithelial cells in a variety of organs, serving to modulate ion flux and/or secretory function.

\section{Acknowledgments}

We are indebted to Marilyn Dixon for preparing this manuscript.

This work was supported by National Institutes of Health grants HD-30276, DK-45923, and HL-46451, and Grants-in-Aid from the American Heart Association (93013540 and 92010890). This project was done during the tenure of Established Investigatorships of the American Heart Association (P. W. Shaul and T. Michel).

\section{References}

1. Lowenstein, C. J., and S. H. Snyder. 1992. Nitric oxide, a novel biologic messenger. Cell. 70:705-707.

2. Dupuy, P. M., S. A. Shore, J. M. Drazen, C. Frostell, W. A. Hill, and W. M. Zapol. 1992. Bronchodilator action of inhaled nitric oxide in guinea pigs. J. Clin. Invest. 90:421-428.

3. Buga, G. M., M. E. Gold, K. S. Wood, G. Chaudhuri, and L. J. Ignarro. 1989. Endothelium-derived nitric oxide relaxes nonvascular smooth muscle. Eur. J. Pharmacol. 161:61-72.

4. Gustaffson, L. E., A. M. Leone, M. G. Persson, N. P. Wiklund, and S. Moncada. 1991. Endogenous nitric oxide is present in the exhaled air of rabbits, guinea pigs and humans. Biochem. Biophys. Res. Commun. 181:852-857.

5. Gaston, B., J. Reilly, J. M. Drazen, J. Fackler, P. Ramdev, D. Arnelle M. E. Mullins, D. J. Sugarbaker, C. Chee, D. J. Singel, et al. 1993. Endogenous nitrogen oxides and bronchodilator $S$-nitrosothiols in human airways. Proc. Natl. Acad. Sci. USA. 90:10957-10961.

6. Stuart-Smith, K., and P. M. Vanhoutte. 1987. Heterogeneity in the effects of epithelium removal in the canine bronchial tree. J. Appl. Physiol. 63:25102515.

7. Kobzik, L., D. S. Bredt, C. J. Lowenstein, J. Drazen, B. Gaston, D. Sug arbaker, and J. S. Stamler. 1993. Nitric oxide synthase in human and rat lung: immunocytochemical and histochemical localization. Am. J. Respir. Cell Mol. Biol. 9:371-377.

8. Schmidt, H. H. H. W., G. D. Gagne, M. Nakane, J. S. Pollock, M. F. Miller, and F. Murad. 1992. Mapping of neuronal nitric oxide synthase in the rat suggests frequent co-localization with NADPH diaphorase but not with soluble guanyly cyclase, and novel paraneuronal functions for nitrinergic signal transduction. $J$. Histochem. Cytochem. 40:1439-1456.

9. Chee, C., B. Gaston, C. Gerard, J. Loscalco, L. Kobzik, J. M. Drazen, and J. Stamler. 1993. Nitric oxide is produced by a human epithelial cell line. Am. Rev. Respir. Dis. 147:433a. (Abstr.)

10. Asano, K., C. Chee, C. M. Lilly, B. Gaston, C. Gerard, J. M. Drazen, and J. S. Stamler. 1994. Activity and gene expression of constitutive and inducible isoforms of nitric oxide synthase in human lung epithelial cells. Am. J. Respir. Crit. Care Med. 149:551a. (Abstr.)

11. Brower, M., D. N. Carney, H. K. Oie, A. F. Gazdar, and J. D. Minna. 1986. Growth of cell lines and clinical specimens of human non-small cell lung cancer in a serum-free defined medium. Cancer Res. 46:798-806.

12. O'Reilly, M. A., A. F. Gazdar, R. E. Morris, and J. A. Whitsett. 1988. Differential effects of glucocorticoid on expression of surfactant proteins in a human lung adenocarcinoma cell line. Biochim. Biophys. Acta. 970:194-204.

13. Voorhout, W. F., T. Veenendaal, Y. Kuroki, Y. Ogasawara, L. M. van Golde, and H. J. Geuze. 1992. Immunocytochemical localization of surfactant protein D (SP-D) in type II cells, Clara cells, and alveolar macrophages of rat lung. J. Histochem. Cytochem. 40:1589-1597.

14. Harkema, J. R., A. Mariassy, J. St. George, D. M. Hyde, and C. G. Plopper 1991. Epithelial cells of the conducting airways: a species comparison. In The Airway Epithelium: Physiology, Pathophysiology, and Pharmacology. S. G. Farmer and D. W. P. Hay, editors. Marcel Dekker, Inc., New York. 3-39.

15. Bredt, D. S., and S. H. Snyder. 1990. Isolation of nitric oxide synthetase, a calmodulin-requiring enzyme. Proc. Natl. Acad. Sci. USA. 87:682-685.

16. Shaul, P. W., and L. B. Wells. 1994. Oxygen modulates nitric oxide production selectively in fetal pulmonary endothelial cells. Am. J. Respir. Cell Mol. Biol. In press.

17. North, A. J., R. A. Star, T. S. Brannon, K. Ujiie, L. B. Wells, C. J. Lowenstein, S. H. Snyder, and P. W. Shaul. 1994. Nitric oxide synthase type I and type II gene expression are developmentally regulated in rat lung. Am. J. Physiol. 266:L635-L641.

18. Bradford, M. M. 1976. A rapid and sensitive method for the quantitation of microgram quantities of protein utilizing the principle of protein-dye binding. Anal. Biochem. 72:248-254.
19. Laemmli, U. K. 1970. Cleavage of structural proteins during the assembly of the head of bacteriophage $\mathrm{T}_{4}$. Nature (Lond.). 227:680-685.

20. Nakane, M., H. H. Schmidt, J. S. Pollock, U. Forstermann, and F. Murad 1993. Cloned human brain nitric oxide synthase is highly expressed in skeletal muscle. FEBS (Fed. Eur. Biochem. Soc.) Lett. 316:175-180.

21. Busconi, L., and T. Michel. 1993. Endothelial nitric oxide synthase: Nterminal myristoylation determines subcellular localization. J. Biol. Chem. 268:8410-8413.

22. Marsden, P. A., K. T. Schappert, H. S. Chen, M. Flowers, C. L. Sundell, J. N. Wilcox, S. Lamas, and T. Michel. 1992. Molecular cloning and characterization of human endothelial nitric oxide synthase. FEBS (Fed. Eur. Biochem. Soc.) Lett. 307:287-293.

23. Ordonez, N. G., and J. G. Batsakis. 1984. Comparison of Ulex europaeus I lectin and Factor VIII-related antigen in vascular lesions. Arch. Pathol. Lab. Med. 108:129-132.

24. Chomczynski, P., and N. Sacchi. 1987. Single-step method of RNA isolation by acid guanidinium thiocyanate-phenol-chloroform extraction. Anal. Biochem. 162:156-159.

25. Ujiie, K., J. Yuen, L. Hogarth, R. Danziger, and R. A. Star. 1994. Localization and regulation of endothelial nitric oxide synthase mRNA expression in the rat kidney. Am. J. Physiol. 267:F296-F302.

26. Bredt, D. S., P. M. Hwang, C. E. Glatt, C. J. Lowenstein, R. R. Reed and S. H. Snyder. 1991. Cloned and expressed nitric oxide synthase structurally resembles cytochrome P-450 reductase. Nature (Lond.). 351:714-718.

27. Lowenstein, C. J., C. S. Glatt, D. S. Bredt, and S. H. Snyder. 1992. Cloned and expressed macrophage nitric oxide synthase contrasts with the brain enzyme. Proc. Natl. Acad. Sci. USA. 89:6711-6715.

28. Nadaud, S., A. Bonnardeaux, M. Lathrop, and F. Soubrier. 1994. Gene structure, polymorphism and mapping of the human endothelial nitric oxide synthase gene. Biochem. Biophys. Res. Commun. 198:1027-1033.

29. Aviv, H., and P. Leder. 1972. Purification of biologically active globin messenger RNA by chromatography on oligothymidilic acid-cellulose. Proc. Natl. Acad. Sci. USA. 69:1408-1412.

30. Thastrup, O., P. J. Cullen, B. K. Drobak, M. R. Hanley, and A. P. Dawson. 1990. Thapsigargin, a tumor promoter, discharges intracellular $\mathrm{Ca}^{2+}$ stores by specific inhibition of the endoplasmic reticulum $\mathrm{Ca}^{2+}$-ATPase. Proc. Natl. Acad. Sci. USA. 87:2466-2470.

31. Ignarro, L. J., and P. J. Kadowitz. 1985. The pharmacological and physiological role of cGMP in vascular smooth muscle relaxation. Annu. Rev. Pharmacol. Toxicol. 25:171-191.

32. Shaul, P. W., M. A. Farrar, and T. M. Zellers. 1992. Oxygen modulates endothelium-derived relaxing factor production in fetal pulmonary arteries. Am J. Physiol. 262:H355-H364.

33. Nijkamp, F. P., H. J. van der Linde, and G. Folerts. 1993. Nitric oxide synthesis inhibition induces airway hyperresponsiveness: role of the epithelium. Am. Rev. Respir. Dis. 147:287a. (Abstr.)

34. Shore, S. A., and L. Romero. 1993. Effect of a nitric oxide synthase inhibitor on bronchoconstriction induced by intravenous histamine. Am. Rev. Respir. Dis. 147:445a. (Abstr.)

35. Xu, X., R. A. Star, G. Tortorici, and S. Muallem. 1994. Depletion of intracellular $\mathrm{Ca}^{2+}$ stores activates nitric oxide synthase to generate cGMP and regulate $\mathrm{Ca}^{2+}$ influx. J. Biol. Chem. 269:12645-12653.

36. Van Scott, M. R., and A. M. Paradiso. 1992. Intracellular $\mathrm{Ca}^{2+}$ and regulation of ion transport across rabbit Clara cells. Am. J. Physiol. 263:L122L127.

37. Cummings, J. J., and H. Wang. 1994. Nitric oxide decreases lung liquid secretion in late gestation fetal sheep. Pediatr. Res. 35:329a. (Abstr.)

38. Schmidt, H. H. H. W., T. D. Warner, K. Ishii, H. Sheng, and F. Murad. 1992. Insulin secretion from pancreatic beta cells caused by L-arginine-derived nitrogen oxides. Science (Wash. DC). 255:721-723.

39. Mantile, G., L. Miele, E. Cordella-Miele, G. Singh, S. L. Katyal, and A. B. Mukherjee. 1993. Human Clara cell $10-\mathrm{kDa}$ protein is the counterpart of rabbit uteroglobin. J. Biol. Chem. 268:20343-20351.

40. Garg, U. C., and A. Hassid. 1989. Nitric oxide-generating vasodilators and 8-bromo-cyclic guanosine monophosphate inhibit mitogenesis and proliferation of cultured rat vascular smooth muscle cells. J. Clin. Invest. 83:1774-1777.

41. Tracey, W. R., J. S. Pollack, F. Murad, M. Nakane, and U. Forstermann. 1994. Identification of an endothelial-like type III NO synthase in LLC-PK 1 kidney epithelial cells. Am. J. Physiol. 266:C22-C28.

42. Salazar, F. J., J. M. Pinilla, F. Lopez, J. C. Romero, and T. Quesada 1992. Renal effects of prolonged synthesis inhibition of endothelium-derived nitric oxide. Hypertension (Dallas). 20:113-117.

43. Siragy, H. M., R. A. Johns, M. J. Peach, and R. M. Carey. 1992. Nitric oxide alters renal function and guanosine 3 ',5'-cyclic monophosphate. Hypertension (Dallas). 19:775-779.

44. Stoos, B. A., O. A. Carretero, R. D. Farhy, G. Scicli, and J. L. Garvin 1992. Endothelium-derived relaxing factor inhibits transport and increases cGMP content in cultured mouse cortical collecting duct cells. J. Clin. Invest. 89:761765 . 